\title{
Formation of vesicles with an organometallic amphiphile bilayer by supramolecular arrangement of metal carbonyl metallosurfactants
}

\author{
Elisabet Parera, ${ }^{a}$ Francesc Comelles, ${ }^{b}$ Ramon Barnadas ${ }^{\ddagger c}$ and Joan Suades ${ }^{* a}$ \\ Received (in $X X X, X X X) X$ th $X X X X X X X X X 200 X$, Accepted Xth $X X X X X X X X X 200 X$ \\ ${ }_{5}$ First published on the web Xth $X X X X X X X X X 200 X$ \\ DOI: $10.1039 / b 000000 x$
}

Metallo-vesicles are formed in water medium as a result of the supramolecular arrangement of molybdenum carbonyl metallosurfactants. These new kind of surfactants contain a ${ }_{10}$ hydrophobic metal carbonyl fragment and are easily prepared from surfactant phosphine ligands.

The study of molecular self-assembly is a central topic in supramolecular chemistry because it is a key knowledge in interdisciplinary areas involving chemistry, biology and new

15 materials. In this context, metallosurfactants (surfactants that contain a metal atom in the molecular structure) are very useful compounds since singular arrangements of metallic compounds can be achieved by means of their molecular selfassembly. ${ }^{1}$ Thus, although this is a relatively recent research 20 field, a wide range of potential applications have been reported, for instance in catalysis, ${ }^{2}$ magnetic resonance imaging, ${ }^{3}$ antiparasitic medications, ${ }^{4}$ mesoporous materials, ${ }^{5}$ metallomesogens, ${ }^{6}$ optoelectronic devices ${ }^{7}$ and nanoparticles. ${ }^{8}$ However, in most of the previous studies the amphiphilic 25 properties of the metallosurfactant are due to the fact that the metal atom acts as the polar head-group of these particular surfactants. In contrast to this strategy, we have prepared metallosurfactants by means of surfactant phosphines, thereby allowing the metal atom to be in any part of the molecule, 30 since the polar head-group is a sulfonate linked to the phosphine ligand. ${ }^{9}, 10$ In particular, we present here the preparation of a new set of metallosurfactants in which the metal atom is located in a characteristic hydrophobic environment, being a neutral metal carbonyl. To our 35 knowledge, there are no studies about the aggregation properties with similar compounds. Only one work has been reported with metal carbonyls but in that study the alkoxy $\operatorname{Re}(\mathrm{I})$ compound does not have an additional polar headgroup, so it is structurally analogous to the main group of 40 metallosurfactants in which the transition metal atom coincides with the polar group. ${ }^{11}$

${ }^{a}$ Departament de Química, Universitat Autònoma de Barcelona, Edifici C, 08193 Bellaterra, Spain. Fax: +34935813101; Tel: +34935812893; Email:Joan.Suades@uab.es

${ }^{b}$ Institut de Química Avançada de Catalunya, CSIC, Jordi Girona, 18-26 08034 Barcelona, Spain

${ }^{c}$ Departament de Fisicoquímica, Facultat de Farmàcia, Universitat de Barcelona, Avda. Joan XXIII s/n, 08028 Barcelona, Spain

$\dagger$ Electronic Supplementary Information (ESI) available: [Experimental details, HRMS spectra and figures with surface tension measurements]. See DOI: $10.1039 / \mathrm{b} 000000 \mathrm{x} /$

"Current address: Departament de Bioquímica i de Biologia Molecular, Edifici M, 08193 Bellaterra, Spain

Two families of new organometallic metallosurfactants were synthesised by means of the coordination of the surfactant phosphines $\mathrm{Ph}_{2} \mathrm{P}\left(\mathrm{CH}_{2}\right)_{\mathrm{n}} \mathrm{SO}_{3} \mathrm{Na}(\mathbf{1}, \mathbf{2}, \mathbf{3})$ to the fragments ${ }_{45}\left\{\mathrm{Mo}(\mathrm{CO})_{5}\right\}$ and $\left\{\mathrm{Mo}\left(\mathrm{CO}_{4}\right\}\right.$ as can be seen in the Schemes 1 and 2. Hence, complexes 4-6 can be regarded as classical surfactants with a bulky hydrophobic group, the $\left\{\mathrm{Ph}_{2} \mathrm{P}-\right.$ $\left.\mathrm{Mo}(\mathrm{CO})_{5}\right\}$ fragment, at the end of the hydrocarbon chain.

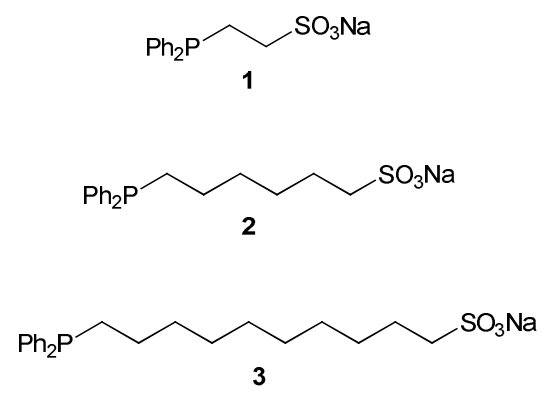

50

Scheme 1 Surfactant phosphine ligands 1-3.

Alternatively, complexes 7-9 can be considered bolaform surfactants since they contain two unities of conventional surfactants $\left(\mathrm{Ph}_{2} \mathrm{P}\left(\mathrm{CH}_{2}\right)_{\mathrm{n}} \mathrm{SO}_{3} \mathrm{Na}\right.$ ligands $)$ linked by a rigid non ${ }_{55}$ polar group (the $\left\{\mathrm{Mo}(\mathrm{CO})_{4}\right\}$ fragment) at the end of the hydrocarbon chains.
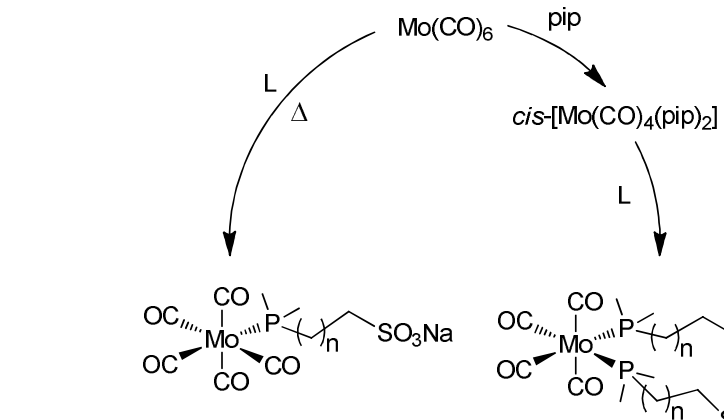

$4(n=1), 5(n=5), 6(n=9)$

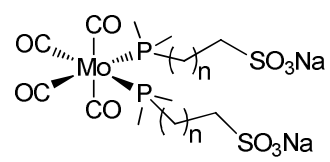

$7(n=1), 8(n=5), 9(n=9)$

Scheme 2 Preparation of molybdenum metallosurfactants $(\mathrm{L}=1,2,3$; pip $=$ piperidine)

${ }_{60}$ Complexes 4-6 were prepared by direct reaction between $\left[\mathrm{Mo}(\mathrm{CO})_{6}\right]$ and the respective phosphine using the procedure reported for TPPTS (triphenylphosphine trisulfonate) ${ }^{12}$ with some modifications such as the reaction media and the workup of reaction products (Scheme 2). Complexes 7-9 were ${ }_{65}$ prepared by the substitution reaction of piperidine in the cis- 
$\left[\mathrm{Mo}(\mathrm{CO})_{4}(\mathrm{pip})_{2}\right]$ complex (pip $=$ piperidine $)$ by the corresponding phosphine ligand using a procedure also similar to that reported for TPPTS (Scheme 2). ${ }^{13,14}$

All compounds were characterised by the usual spectroscopic 5 methods and their stability in water medium was studied by

${ }^{31} \mathrm{P}$ NMR spectroscopy. Results showed that water solutions of complexes 4-9 are sufficiently stable to undergo studies of their aggregation properties (decomposition values were under $5 \%$ in 24 hours).

10 The metallosurfactant character of 4-9 was proven by surface tension measurements that evidenced in all cases the characteristic decrease as concentration increases until reaching the critical micelle concentration $(\mathrm{cmc})$ as shown in Figure 1.

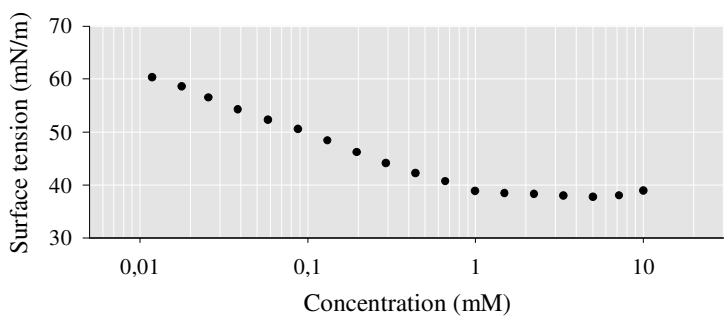

Figure 1 Surface tension measurements for complex 5.

The cmc values for complexes 4-9 are significantly lower than those for the respective ligand as can be seen in Table 1. A similar behaviour has been reported for other 20 metallosurfactants with $\mathrm{ML}_{2}$ stoichiometry. This has been related to the structural analogy between these molecules and gemini surfactants $^{9}$ or bolamphiphiles. ${ }^{10}$ It should be emphasised that the present study allows a new kind of comparison because compounds 4-6 and 7-9 are the first 25 example of two families of similar metallosurfactants with the stoichiometries $\mathrm{ML}$ and $\mathrm{ML}_{2}$ that can be compared with the free surfactant ligands $\mathbf{1 - 3}$. It is noteworthy that no significant differences were observed between the $\mathrm{cmc}$ values of ML (46) and $\mathrm{ML}_{2}$ (7-9) complexes. The cmc diminution in 4-6 30 respect to the free phosphines 1-3 can be associated to an increase in the hydrophobicity as a result of the addition of the lipophilic carbonyl fragments $\left\{\mathrm{Mo}(\mathrm{CO})_{5}\right\}$. This result is consistent with the idea that, in contrast to metallosurfactants in which the transition metal is the polar headgroup, in these 35 compounds the addition of metal increases the hydrophobic character of the molecule.

The calculus of the area occupied per molecule adsorbed in the water/air interface from the slope of the linear decrease of surface tension below the $\mathrm{cmc}$ via the Gibbs equation $(\Gamma=-$

${ }_{40}(\mathrm{~d} \gamma / \mathrm{d} \log \mathrm{C}) / 2.303 \mathrm{nRT} ; \Gamma=$ surface excess concentration, $\mathrm{n}=$ number of molecular species in solution) is a common approach in the study of surfactants that has recently been questioned. ${ }^{15}$ However, we have included these data in Table 1 because they are useful for comparison purposes only. Thus, 45 the effect of hydrocarbon chain length on this value shows different trends for the three families of compounds displayed in Table 1. Whereas for the free phosphines (1-3) the data are nearly identical, a substantial increase is observed from $\mathbf{4}$ to $\mathbf{6}$. This result agrees with the hypothesis that the influence of 50 chain length in packing at the air-water interface is minimal with ligands 1-3 but it becomes relevant after the addition of the hydrophobic $\left\{\mathrm{Mo}(\mathrm{CO})_{5}\right\}$ fragment. For complexes 7-9, a relatively small increase is observed from $\mathbf{7}$ to $\mathbf{8}$, whereas a great increment is produced from 8 to $\mathbf{9}$. This singular 55 behaviour is consistent with previous data with cis- $\left[\mathrm{PtCl}_{2} \mathrm{~L}_{2}\right]$ $(\mathrm{L}=\mathbf{1}, 2,3)$ complexes ${ }^{10}$ and it concords with the idea that complex 9 could adopt a double loop conformation in the interface as is shown in Figure 2.

Table 1 Calculated parameters from surface tension measurements: 60 critical micelle concentration $(\mathrm{cmc})$, surface excess concentration $(\Gamma)$, estimated area occupied per molecule adsorbed in the water/air interface via Gibbs equation (A).

\begin{tabular}{cccc}
\hline Compound & $\mathrm{cmc}(\mathrm{mM})$ & $\Gamma\left(\mathrm{mol} / \mathrm{cm}^{2}\right)$ & $\mathrm{A}\left(\AA^{2}\right)$ \\
\hline $\mathbf{1}$ & 14 & $(1.7 \pm 0.1) \times 10^{-10}$ & 99 \\
$\mathbf{2}$ & 4.0 & $(1.64 \pm 0.03) \times 10^{-10}$ & 101 \\
$\mathbf{3}$ & $0.5-1.2$ & $(1.6 \pm 0.2) \times 10^{-10}$ & 100 \\
\hline $\mathbf{4}$ & 2.0 & $(1.75 \pm 0.04) \times 10^{-10}$ & 95 \\
$\mathbf{5}$ & 1.2 & $(9.9 \pm 0.3) \times 10^{-11}$ & 167 \\
$\mathbf{6}$ & 0.15 & $(8.9 \pm 0.8) \times 10^{-11}$ & 190 \\
$\mathbf{7}$ & 1.9 & $(1.2 \pm 0.1) \times 10^{-10}$ & 140 \\
$\mathbf{8}$ & 0.84 & $(8.7 \pm 0.3) \times 10^{-11}$ & 192 \\
$\mathbf{9}$ & 0.28 & $(4.9 \pm 0.4) \times 10^{-11}$ & 340 \\
\hline
\end{tabular}

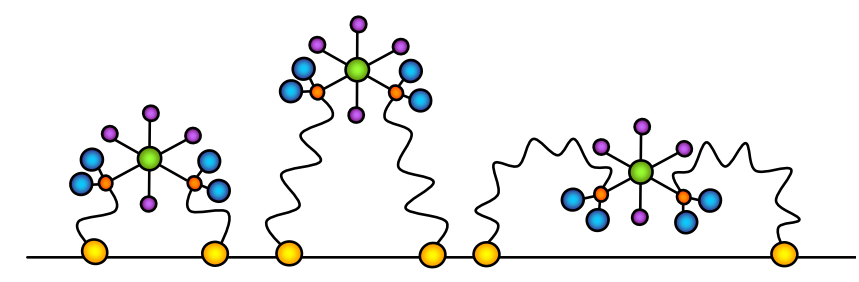

65

Figure 2 Schematic representations of complexes 7-9 in the interface showing the double-loop conformation for $\mathbf{9}$ (sulfonate groups are represented by yellow balls).

The study of supramolecular aggregates formed in water 70 solutions of compounds 4-9 at concentrations above the $\mathrm{cmc}$ was performed by means of Dynamic Light Scattering spectroscopy (DLS) and cryo-TEM microscopy. The DLS results agree with the formation of medium and large size polydisperse vesicles in all cases average hydrodynamic 75 diameter of aggregates in $\mathrm{nm}: 225 \pm 4$ (4), $147 \pm 2$ (5), 200 \pm 20

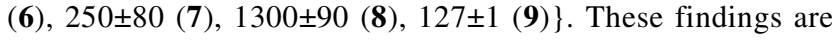
consistent with previous studies that have shown a tendency for amphiphilic metal complexes to aggregate yielding vesicles instead of micelles. ${ }^{10,16,17}$ This behaviour has been 80 related to the changes in the shape of molecules after metal coordination which favours self-assembly as vesicles. ${ }^{10,17}$

Cryo-TEM microscopy analysis of water solutions of compounds 4-9 corroborated the formation of polydisperse spherical vesicles in all cases. The micrographies show a wide 85 range of aggregates with some morphological differences as it is nicely shown in Figure 3. This picture is very interesting because in a sole image we can observe: (a) small unilamellar vesicles (SUV, small spheres of diameters lower than 100 $\mathrm{nm}$ ), (b) large unilamellar vesicles (LUV, large spheres of 90 diameters higher than $100 \mathrm{~nm}$ ), (c) multilamellar vesicles (MLV, they have an onion-like structure), (d) multilamellar multivesicular vesicles (they do not have the onion structure, they consist of many smaller non concentric spheres inside a 
larger vesicle).

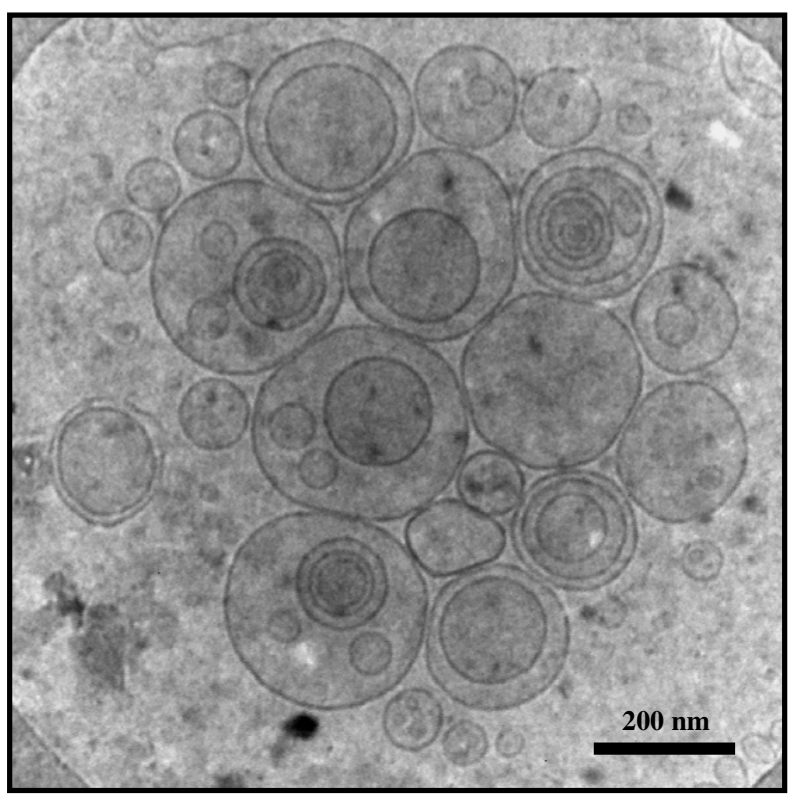

Figure 3 Cryo-TEM micrograph of a solution of $\mathbf{5}$ in water 5 (concentration: $7.3 \mathrm{mM}$ ).

In summary, we have shown that metallosurfactants with a metal carbonyl fragment in the hydrophobic part of the molecule exhibit a tendency to form vesicles in a similar way as other special surfactants such as fullerene derivatives. ${ }^{18}$

10 The main difference is that in the present work the walls of these vesicles contain a metallic amphiphile bilayer as can be visualized in Figure 4.

This work was supported by the Dirección General de Investigación (Project CTQ2007-63913). We thank Dr. Emma 15 Rossinyol for valuable assistance with the cryo-TEM studies, to Prof. Joan Estelrich for DLS measurements and to Ms. Estel López for the design of Figure 4.

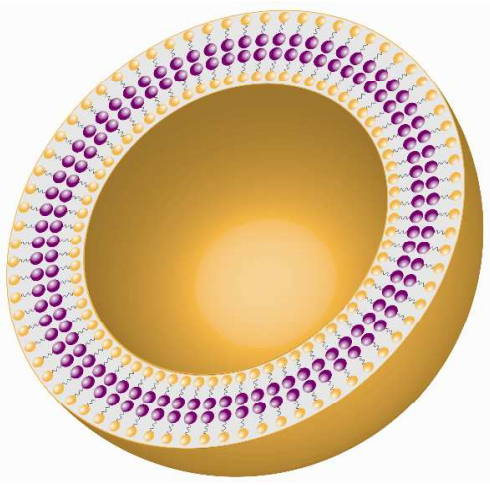

20

Figure 4 Schematic representations of a metallo-vesicle showing the organometallic amphiphile bilayer (yellow and purple balls respectively represents sulfonate and $\left\{\mathrm{Ph}_{2} \mathrm{PMo}(\mathrm{CO})_{5}\right\}$ groups).

\section{${ }_{25}$ Notes and references}

1 (a) P. C. Griffiths, I. A. Fallis, T. Tatchell, L. Bushby, A. Beeby, Adv. Colloid Interface Sci., 2008, 144, 13. (b) A. Guerrero-Martínez, Y. Vida, D. Domıínguez-Gutiérrez, R. Q. Albuquerque, L. De Cola, Inorg. Chem., 2008, 47, 9131. (c) P. C. Griffiths, I. A. Fallis, C.

30 James, I. R. Morgan, G. Brett, R. K. Heenan, R. Schweins, I. Grilloc, A. Paul, Soft Matter, 2010, 6, 1981.

2 See for instance: (a) B. E. Hanson, H. Ding, C. W. Kohlpaintner, Catal. Today, 1998, 42, 421. (b) M. S. Goedheijt, B. E. Hanson, J. N. H. Reek, P. C. J. Kamer, P.W. N. M. van Leeuwen, J. Am. Chem. 35 Soc., 2000, 122, 1650. (c) B. H. Lipshutz, S. Ghorai, Org. Lett., 2009, 11, 705. (d) F. Mancina, P. Scrimina, P. Tecilla, U. Tonellato, Coord. Chem. Rev., 2009, 253, 2150. (e) J. Zhang, X. Meng, X. Zeng, X. Yu, Coord. Chem. Rev., 2009, 253, 2166.

3 (a) P. Caravan, M. T.Greenfield, X. D. Li, A. D. Sherry, Inorg.

40 Chem., 2001, 40, 6580. (b) X. D. Li, S. R. Zhang, P. Y. Zhao, Z. Kovacs, A. D. Sherry, Inorg. Chem., 2001, 40, 6572. (c) R. Hovland, C. Gløgård, A. J. Aasen, J. J. Klaveness, Org. Biomol. Chem., 2003, 1, 644. (d) M. Vaccaro, G. Mangiapia, A. Radulescu, K. Schillén, G. D’Errico, G. Morelli, L. Paduano, Soft Matter, 2009, 5, 2504.

454 G.W. Walker, R. J. Geue, A. M. Sargeson, C. A. Behm, Dalton Trans., 2003, 2992.

5 (a) V. W. W Yam, B. Li, N. Zhu, Adv. Mater., 2002, 14, 719. (b) K. E. Amos, N. J. Brooks, N. C. King, Songhai Xie, J. CanalesVázquez, M. J. Danks, H. B. Jervis, W. Zhou, J. M. Seddon, D. W. $50 \quad$ Bruce, J. Mater. Chem., 2008, 18, 5282.

6 (a) B. Donnio, Curr. Opin. Colloid Interface Sci., 2002, 7, 371. (b) M. Iida, M. Inoue, T. Tanase, T. Takeuchi, M. Sugibayashi, K. Ohta, Eur. J. Inorg. Chem., 2004, 3920. (c) T. Cardinaels, J. Ramaekers, K. Driesen, P. Nockemann, K. Van Hecke, L. Van Meervelt, B. Goderis, K. Binnemans, Inorg. Chem., 2009, 48, 2490.

7 (a) N. Terasaki, T. Akiyama, S. Yamada, Langmuir, 2002, 18, 8666 (b) M. K. Nazeeruddin, S. M. Zakeeruddin, J. J. Lagref, P. Liska, P. Comte, C. Barolo, G. Viscardi, K. Schenk, M. Graetzel, Coord. Chem. Rev., 2004, 248, 1317. (c) H. D. Jayathilake, J. A. Driscoll, A. N. Bordenyuk, L. Wu, S. R. P. da Rocha, C. N. Verani, A. V. Benderskii, Langmuir, 2009, 25, 6880. (d) H. J. Bolink, E. Baranoff, M. Clemente-León, E. Coronado, N. Lardiés, A. López-Muñoz, D. Repetto, Md. K. Nazeeruddin, Langmuir, 2010, 26, 11461.

8 (a) H. Er, S. Ohkawa, M. Iida, Colloids Surf. A, 2007, 301, 189. (b)

65 M. Iida, C. Baba, M. Inoue, H. Yoshida, E. Taguchi, H. Furusho, Chem. Eur. J., 2008, 14, 5047.

9 E. Valls, A. Solsona, J. Suades, R. Mathieu, F. Comelles C. LópezIglesias, Organometallics, 2002, 21, 2473.

10 E. Parera, F. Comelles, R. Barnadas, J. Suades, Langmuir, 2010, 26, 743.

11 P. Thanasekaran, J.Y. Wu, B. Manimaran, T. Rajendran, I. J. Chang, S. Rajagopal, G. H. Lee, S.M. Peng, K. L. Lu, J. Phys. Chem. A, 2007, 111, 10953.

12 C. Larpent, H. Patin, Appl. Organomet. Chem., 1987, 1, 529.

7513 D. J. Darensbourg, R. L. Kump, Inorg. Chem., 1978, 17, 2680.

14 D. J. Darensbourg, C. J. Bischoff, Inorg. Chem., 1993, 32, 47.

15 (a) F. M. Menger, L. Shi, S. A. A. Rizvi, J. Am. Chem. Soc., 2009, 131, 10380. (b) F. M. Menger, L. Shi, S. A. A. Rizvi, Langmuir, 2010, 26, 1588.

8016 (a) N. A. J. M. Sommerdijk, K. J. Booy, A. M. A. Pistorius, M. C Feiters, R. J. M. Nolte, B. Zwanenburg, Langmuir, 1999, 15, 7008. (b) X. Luo, S. Wu, Y. Liang, Chem. Commun., 2002, 5, 492. (c) X. Luo, W. Miao, S. Wu, Y. Liang, Langmuir, 2002, 18, 9611. (d) M. Apostol, P. Baret, G. Serratrice, J. Desbrières, J. Putaux, M. J.Stébé, D. Expert, J. Pierre, Angew. Chem., Int. Ed., 2005, 44, 2580.

17 (a) J. S. Martinez, G. P. Zhang, P. D. Holt, H. T. Jung, C. J. Carrano, M. G. Haygood, A. Butler, Science, 2000, 287, 1245. (b) T. Owen, R. Pynn, J. S. Martinez, A. Butler, Langmuir, 2005, 21, 12109. (c) T. Owen, R. Pynn, B. Hammouda, A. Butler, Langmuir, 2007, 23, 9393. (d) T. Owen, S. M. Webb, A. Butler, Langmuir, 2008, 24, 4999.

18 S. Zhou, C. Burger, B. Chu, M. Sawamura, N. Nagahama, M. Toganoh, U. E. Hackler, H. Isobe, E. Nakamura, Science, 2001, 291, 1944. 


\title{
Formation of vesicles with an organometallic amphiphile bilayer by supramolecular arrangment of metal carbonyl metallosurfactants
}

\author{
Elisabet Parera, ${ }^{\text {a }}$ Francesc Comelles, ${ }^{\text {b }}$ Ramon Barnadas ${ }^{c}$ and Joan Suades ${ }^{* a}$
}

\author{
åDepartament de Química, Universitat Autònoma de Barcelona, Edifici C, 08193 Bellaterra, Spain. \\ ${ }^{b}$ Institut de Química Avançada de Catalunya, CSIC, Jordi Girona, 18-26, 08034 Barcelona, Spain \\ ${ }^{\mathrm{c}}$ Departament de Fisicoquímica, Facultat de Farmàcia, Universitat de Barcelona, Avda. Joan XXIII s/n, \\ 08028 Barcelona, Spain
}

\section{Table of Contents:}

1. General Information 1

2. Synthesis of Complexes 4-9 2

3. High Resolution Mass Spectrometry 5

4. Surface Tension Measurements 11

\section{General Information}

All reactions were performed under nitrogen using standard Schlenk tube techniques. Tetrahydrofuran and methanol were distilled (respectively, over sodium/benzophenone and magnesium) and stored over $3 \AA$ molecular sieve. Pentane was dried with $3 \AA$ molecular sieve. Infrared spectra were recorded with a Perkin-Elmer 2000 FT spectrometer. The NMR spectra were recorded in the Servei de Ressonància Magnètica Nuclear de la Universitat Autònoma de Barcelona on Bruker DPX-250, DPX-360 and AV400 instruments. Microanalyses were performed by the Servei d'Anàlisi Química del Departament de Química de la Universitat Autònoma de Barcelona. Mass spectra and exact mass measurements were respectively obtained on an Esquire 3000 with electrospray ionization and an ion trap Bruker Daltonics and on a Bruker microTOFQ with electrospray ionization Apollo of Bruker by Servei d'Anàlisi Química del Departament de Química de la Universitat Autònoma de Barcelona.

The Dynamic Light Scattering measurements were performed in the Departament de Fisicoquímica de la Facultat de Farmàcia de la Universitat de Barcelona using a Malvern Zetasizer ZS90 (Malvern Instruments Ltd, Malvern, UK) equipped with an He-Ne laser. In this 
device scattered light is detected at $90^{\circ}$ and its intensity on the detector is automatically adjusted in order to achieve an optimal range. This fact allows the analysis of several orders of sample concentration, avoiding their dilution and, consequently, changes in the phase equilibrium. The DLS instrument used for these experiments can be used to characterize particles with diameters in the range $2 \mathrm{~nm}-6 \mu \mathrm{m}$. All compounds were previously recrystallized. The water solutions of amphiphiles (4: $10.9 \mathrm{mM}$; 5: $7.3 \mathrm{mM}$; 6: $3.4 \mathrm{mM}$; 7: $10.5 \mathrm{mM}$; 8: $9.1 \mathrm{mM}$; 9: $3.7 \mathrm{mM}$ ) were prepared with degassed Milli-Q water. The solutions were previously centrifuged for $2-3$ minutes at $13000 \mathrm{rpm}$ and then aged for at least 1 hour before measurements. For all DLS measurements the temperature was $25 \pm 0.5^{\circ} \mathrm{C}$. Each data acquisition was a mean of 10 consecutive analyses and each experiment was repeated three times. The data were analyzed by cumulant method using the software provided by the manufacturer. Polydispersity index of the samples corresponded to polydisperse vesicles (4: $0.41 \pm 0.05 ; 5: 0.46 \pm 0.02 ; 6: 0.7 \pm 0.2 ; 7$ : $0.56 \pm 0.06 ; 8: 0.34 \pm 0.05 ; 9: 0.50 \pm 0.01)$ in agreement with cryo-TEM microscopy analysis. The microscopy studies were performed in the Servei de Microscòpia Electrònica de la Universitat Autònoma de Barcelona. Micrographs were obtained using a Jeol JEM-1400 electron microscope operating at $120 \mathrm{kV}$ and equipped with a CCD multiscan camera (Gatan). The microscope was equipped with a Gatan cryoholder and the samples were maintained at $-177^{\circ} \mathrm{C}$ during imaging. Micro drops $(2 \mu \mathrm{L})$ of the water solutions of amphiphiles were blotted onto holey carbon grids (Quantifoil) previously glow discharged in an BAL-TEC MSC 010 glow discharger unit, which were immediately plugged into liquid ethane at $-180{ }^{\circ} \mathrm{C}$ using a Leica EM CPC cryoworkstation.

\section{Synthesis of Complexes 4-9}

Complexes 4, 5, 6: The phosphine $\mathrm{Ph}_{2} \mathrm{P}\left(\mathrm{CH}_{2}\right)_{\mathrm{n}} \mathrm{SO}_{3} \mathrm{Na}\{0.22 \mathrm{mmol}(0.070 \mathrm{~g}$ for 4, $0.082 \mathrm{~g}$ for 5 and $0.095 \mathrm{~g}$ for 6) $\}$ was dissolved in dry methanol $(10 \mathrm{~mL}$ for 4 and 5; $15 \mathrm{~mL}$ for 6) and this solution was added at room temperature to a solution of $\left[\mathrm{Mo}(\mathrm{CO})_{6}\right](0.584 \mathrm{~g}, 2.21 \mathrm{mmol})$ in freshly distilled THF (40 mL). The resulting solution was protected from light and heated with a bath at $80^{\circ} \mathrm{C}$ for 15 hours under nitrogen atmosphere. The obtained yellow solution was cooled, getting dark as temperature decreases and becoming black at to room temperature. Next, solvent was evaporated under reduced pressure to dryness to yield a black solid that was washed $(3 \times 20$ $\mathrm{mL})$ with dry pentane in order to remove $\left[\mathrm{Mo}(\mathrm{CO})_{6}\right]$ excess. Dry methanol $(50 \mathrm{~mL}$ for 4 and 5; $75 \mathrm{~mL}$ for 6) was added to the residual solid and after vigorous stirring the resulting mixture was 
centrifuged (5000 rpm) and filtered with Celite. The complexes were isolated as brown solids after evaporation of filtrate to dryness under reduced pressure.

$\left[\mathrm{Mo}(\mathrm{CO})_{5}(\mathbf{1})\right](4)$ : The above procedure leads to $85 \mathrm{mg}$ of $4(70 \%)$. IR $\left(\mathrm{CH}_{2} \mathrm{Cl}_{2}, \mathrm{~cm}^{-1}\right): 2073$, 1990, $1945\{v(\mathrm{CO})\} .{ }^{31} \mathrm{P}\left\{{ }^{1} \mathrm{H}\right\}-\mathrm{NMR}\left(\mathrm{CD}_{3} \mathrm{OD}, \delta\right.$ in ppm): 26.7 (s). ${ }^{1} \mathrm{H}-\mathrm{NMR}\left(\mathrm{CD}_{3} \mathrm{OD}, \delta\right.$ in ppm): 2.62 - 2.73 (m, PC $\left.\underline{H}_{2}\right), 2.89$ - $3.00\left(\mathrm{~m}, \underline{\mathrm{C}}_{2} \mathrm{~S}\right), 7.45$ - 7.69 (m, Ph). MS-ESI (negative mode, $m / z): 446.8$ ([M-3CO-Na]', $100 \%), 474.8$ ([M-2CO-Na]', $15 \%)$. HRMS (ESI) calcd for $\mathrm{C}_{19} \mathrm{H}_{14} \mathrm{MoO}_{8} \mathrm{PS}$ ([M-Na] $]^{-}$530.9209, found 530.9199. Anal. Found: C, 41.12; H, 2.60; S, 5.63. Calcd for $\mathrm{C}_{19} \mathrm{H}_{14} \mathrm{MoNaO}_{8} \mathrm{PS}$ : C, 41.32; H, 2.56; S, 5.81.

$\left[\mathrm{Mo}(\mathrm{CO})_{5}(2)\right](5)$ : The above procedure leads to $90 \mathrm{mg}$ of $5(67 \%)$. IR $\left(\mathrm{CH}_{2} \mathrm{Cl}_{2}, \mathrm{~cm}^{-1}\right): 2072$, 1988, $1944\{v(\mathrm{CO})\} .{ }^{31} \mathrm{P}\left\{{ }^{1} \mathrm{H}\right\}-\mathrm{NMR}\left(\mathrm{CD}_{3} \mathrm{OD}, \delta\right.$ in ppm): 27.2 (s). ${ }^{1} \mathrm{H}-\mathrm{NMR}\left(\mathrm{CD}_{3} \mathrm{OD}, \delta\right.$ in ppm): 1.32 - 1.49 (m, $\mathrm{PCH}_{2} \underline{\mathrm{C}}_{2} \mathrm{C}_{2} \underline{\mathrm{C}}_{2}$ ), 1.56 - 1.70 (m, $\underline{\mathrm{C}}_{2} \mathrm{CH}_{2} \mathrm{~S}$ ), $2.41-2.56$ (m, $\mathrm{PC} \underline{H}_{2}$ ), 2.70 $2.80\left(\mathrm{~m}, \underline{\mathrm{C}}_{2} \mathrm{~S}\right), 7.42$ - 7.68 (m, Ph). MS-ESI (negative mode, $\left.\mathrm{m} / z\right)$ ) 586.9 ([M-Na]', $100 \%$ ), HRMS (ESI) calcd for $\mathrm{C}_{23} \mathrm{H}_{22} \mathrm{MoO}_{8} \mathrm{PS}$ ([M-Na] $\left.]^{-}\right)$586.9836, found 586.9820. Anal. Found: C, 45.28; H, 3.53; S, 5.12. Calcd for $\mathrm{C}_{23} \mathrm{H}_{22} \mathrm{MoNaO}_{8} \mathrm{PS}$ : C, 45.41; H, 3.64; S, 5.27.

$\left[\mathrm{Mo}(\mathrm{CO})_{5}(3)\right](6)$ : The above procedure leads to $84 \mathrm{mg}$ of $6(57 \%)$. IR $\left(\mathrm{CH}_{2} \mathrm{Cl}_{2}, \mathrm{~cm}^{-1}\right): 2071$, 1988, $1943\{v(\mathrm{CO})\} .{ }^{31} \mathrm{P}\left\{{ }^{1} \mathrm{H}\right\}-\mathrm{NMR}\left(\mathrm{CD}_{3} \mathrm{OD}, \delta\right.$ in ppm): 27.4 (s). ${ }^{1} \mathrm{H}-\mathrm{NMR}\left(\mathrm{CD}_{3} \mathrm{OD}, \delta\right.$ in ppm): 1.13 - 1.47 (m, $\left.\mathrm{PCH}_{2}\left(\mathrm{C}_{2}\right)_{7}\right), 1.71$ - 1.82 (m, $\left.\underline{\mathrm{C}}_{2} \mathrm{CH}_{2} \mathrm{~S}\right), 2.41$ - 2.50 (m, $\left.\mathrm{PC} \underline{H}_{2}\right), 2.73$ - 2.82 (m, $\mathrm{C}_{2} \mathrm{~S}$ ), 7.44 - 7.59 (m, Ph). MS-ESI (negative mode, $\left.\mathrm{m} / z\right)$ ) 642.9 ([M-Na]', $100 \%$ ). HRMS (ESI) calcd for $\mathrm{C}_{27} \mathrm{H}_{30} \mathrm{MoO}_{8} \mathrm{PS}$ ([M-Na] $]^{-}$) 643.0464, found 643.0447. Anal. Found: C, 48.45; H, 4.37; S, 4.56. Calcd for $\mathrm{C}_{27} \mathrm{H}_{30} \mathrm{MoNaO}_{8} \mathrm{PS}$ : C, 48.40; H, 4.55; S, 4.83.

Complexes 7, 8, 9: The phosphine $\mathrm{Ph}_{2} \mathrm{P}\left(\mathrm{CH}_{2}\right)_{n} \mathrm{SO}_{3} \mathrm{Na}\{0.119 \mathrm{~g}(0.37 \mathrm{mmol})$ for 7, $0.208 \mathrm{~g}(0.56$ $\mathrm{mmol})$ for $\mathbf{8}, 0.219 \mathrm{~g}(0.51 \mathrm{mmol})$ for $\mathbf{9}$ \} was dissolved in dry methanol (10 mL for $\mathbf{7}$ and $\mathbf{8} ; 20$ $\mathrm{mL}$ for 9) and this solution was slowly added at room temperature to a solution of cis$\left[\mathrm{Mo}(\mathrm{CO})_{4}(\text { pip })_{2}\right]($ pip = piperidine, $0.070 \mathrm{~g}, 0.19 \mathrm{mmol})$ in dry THF $(10 \mathrm{~mL})$. The resulting solution was protected from light and allowed to stir at room temperature for 3 hours under nitrogen atmosphere. At this point, a clear yellow solution should be obtained. If some turbidity was observed, it can be related with the use of solvents that were not dry enough. This clear yellow solution was evaporated under reduced pressure to dryness to yield a yellow solid. Dry methanol $(0.5 \mathrm{~mL}$ for $\mathbf{7}$ and $\mathbf{8} ; 1.5 \mathrm{~mL}$ for $\mathbf{9})$ was added to this solid and after vigorous stirring the resulting mixture was centrifuged (13000 rpm). Freshly distilled diethyl ether was dropwise added to the filtrate until the precipitation of a yellow solid is complete $(\approx 2 \mathrm{~mL})$. The precipitate was isolated by centrifugation $(13000 \mathrm{rpm})$, washed with diethyl ether $(2 \times 1 \mathrm{~mL})$ and dried under reduced pressure. Complexes 7, 8, 9 were isolated as yellow solids. 
cis-[Mo(CO $\left.)_{4}(\mathbf{1})_{2}\right](7)$ : The above procedure leads to $127 \mathrm{mg}$ of $7(82 \%)$. IR $\left(\mathrm{CH}_{2} \mathrm{Cl}_{2}, \mathrm{~cm}^{-1}\right)$ : 2020, 1925, $1897\{v(\mathrm{CO})\} .{ }^{31} \mathrm{P}\left\{{ }^{1} \mathrm{H}\right\}-\mathrm{NMR}\left(\mathrm{CD}_{3} \mathrm{OD}, \delta\right.$ in ppm): 25.6 (s). ${ }^{1} \mathrm{H}-\mathrm{NMR}\left(\mathrm{CD}_{3} \mathrm{OD}, \delta\right.$ in ppm): 2.43 - 2.62 (m, PC $\left.\underline{H}_{2}\right), 2.69-2.84$ (m, $\left.\underline{\mathrm{CH}}_{2} \mathrm{~S}\right), 7.24-7.90$ (m, Ph). ${ }^{13} \mathrm{C}-\mathrm{NMR}\left(\mathrm{CD}_{3} \mathrm{OD}, \delta\right.$ in ppm): $28.3\left(\mathrm{AXX}, 3\right.$ lines, ${ }^{1} \mathrm{~J}_{\mathrm{C}-\mathrm{P}+}{ }^{3} \mathrm{~J}_{\mathrm{C}-\mathrm{P}}$ ' $\left.=20.4 \mathrm{~Hz}, \mathrm{P} \underline{\mathrm{C}} \mathrm{H}_{2}\right), 46.4\left(\mathrm{~s}, \underline{\mathrm{C}} \mathrm{H}_{2} \mathrm{~S}\right), 128.2-135.7$ (multiple signals, $\mathrm{Ph}$ ), $209.3\left(\mathrm{t},{ }^{2} \mathrm{~J}_{\mathrm{C}-\mathrm{P}}=9.4 \mathrm{~Hz}, \mathrm{CO}\right.$ cis to the two $\mathrm{P}$ atoms), 214.8 (AXX', 3 lines, ${ }^{2} \mathrm{~J}_{\mathrm{C}-\mathrm{P}}+{ }^{2} \mathrm{~J}_{\mathrm{C}-\mathrm{P}},=15.8 \mathrm{~Hz}, \mathrm{CO}$ trans and cis to $\mathrm{P}$ atoms). MS-ESI (negative mode, $\mathrm{m} / \mathrm{z}$ ): 818.8 ([M$\mathrm{Na}]^{-}, 55 \%$ ). HRMS (ESI) calcd for $\mathrm{C}_{32} \mathrm{H}_{28} \mathrm{MoNaO}_{10} \mathrm{P}_{2} \mathrm{~S}_{2}$ ([M-Na]') 818.9550, found 818.9550. Anal. Found: C, 45.34; H, 3.56; S, 7.31. Calcd for $\mathrm{C}_{32} \mathrm{H}_{28} \mathrm{MoNa}_{2} \mathrm{O}_{10} \mathrm{P}_{2} \mathrm{~S}_{2} \cdot 0.5 \mathrm{CH}_{4} \mathrm{O}: \mathrm{C}, 45.57$; , $3.53 ; \mathrm{S}, 7.49$.

cis- $\left[\mathrm{Mo}(\mathrm{CO})_{4}(2)\right](8)$ : The above procedure leads to $150 \mathrm{mg}$ of $\mathbf{8}(85 \%)$. IR $\left(\mathrm{CH}_{2} \mathrm{Cl}_{2}, \mathrm{~cm}^{-1}\right)$ : 2015, 1914, 1896, $1868\{v(\mathrm{CO})\} .{ }^{31} \mathrm{P}\left\{{ }^{1} \mathrm{H}\right\}-\mathrm{NMR}\left(\mathrm{CD}_{3} \mathrm{OD}, \delta\right.$ in ppm): 26.3 (s). ${ }^{1} \mathrm{H}-\mathrm{NMR}$ (CD ${ }_{3} \mathrm{OD}, \delta$ in ppm): 1.07 - 1.16 (m, $\left.\mathrm{PCH}_{2} \underline{\mathrm{C}}_{2}\right), 1.16$ - 1.25 (m, $\left.\mathrm{PCH}_{2} \mathrm{CH}_{2} \mathrm{C}_{2} \underline{\mathrm{C}}_{2} \underline{H}_{2}\right), 1.59-1.69$ (m, $\underline{\mathrm{C}}_{2} \mathrm{CH}_{2} \mathrm{~S}$ ), $2.00-2.08$ (m, PC $\left.\underline{H}_{2}\right), 2.66-2.73$ (m, $\underline{\mathrm{C}}_{2} \mathrm{~S}$ ), $7.31-7.41$ (m, Ph). ${ }^{13} \mathrm{C}-\mathrm{NMR}$ $\left(\mathrm{CD}_{3} \mathrm{OD}, \delta\right.$ in ppm): 23.9 (s, $\left.\mathrm{PCH}_{2} \underline{C} \mathrm{H}_{2}\right), 24.4\left(\mathrm{~s}, \underline{\mathrm{C}} \mathrm{H}_{2} \mathrm{CH}_{2} \mathrm{~S}\right), 28.0$ (s, $\left.\underline{C} \mathrm{H}_{2} \mathrm{CH}_{2} \mathrm{CH}_{2} \mathrm{~S}\right), 30.3$ (AXX', 3 lines, ${ }^{2} \mathrm{~J}_{\mathrm{C}-\mathrm{P}+}{ }^{4} \mathrm{~J}_{\mathrm{C}-\mathrm{P}}$, = $\left.12.8 \mathrm{~Hz}, \mathrm{PCH}_{2} \mathrm{CH}_{2} \mathrm{CH}_{2}\right), 32.2\left(\mathrm{AXX}, 3\right.$ lines, ${ }^{1} \mathrm{~J}_{\mathrm{C}-\mathrm{P}}+{ }^{3} \mathrm{~J}_{\mathrm{C}-\mathrm{P}}$, $=21.7$ $\mathrm{Hz}, \mathrm{PC} \underline{H}_{2}$ ), 51.0 (s, $\underline{\mathrm{CH}}_{2} \mathrm{~S}$ ), 127.9-137.1 (multiple signals, $\mathrm{Ph}$ ), 210.0 (t, ${ }^{2} \mathrm{~J}_{\mathrm{C}-\mathrm{P}}=9.4 \mathrm{~Hz}, \mathrm{CO}$ cis to the two $\mathrm{P}$ atoms), 215.3 ( $\mathrm{AXX}$, 3 lines, ${ }^{2} \mathrm{~J}_{\mathrm{C}-\mathrm{P}+}{ }^{2} \mathrm{~J}_{\mathrm{C}-\mathrm{P}},=15.9 \mathrm{~Hz}, \mathrm{CO}$ trans and cis to $\mathrm{P}$ atoms). MS-ESI (negative mode, $m / z)$ ) 931.0 ([M-Na]', $70 \%$ ). HRMS (ESI) calcd for $\mathrm{C}_{40} \mathrm{H}_{44} \mathrm{MoNaO}_{10} \mathrm{P}_{2} \mathrm{~S}_{2}$ ([M-Na] $]^{-}$931.0805, found 931.0795. Anal. Found: C, 49.78; H, 5.02; S, 6.28. Calcd for $\mathrm{C}_{40} \mathrm{H}_{44} \mathrm{MoNa}_{2} \mathrm{O}_{10} \mathrm{P}_{2} \mathrm{~S}_{2} \cdot \mathrm{CH}_{4} \mathrm{O}: \mathrm{C}, 50.00 ; \mathrm{H}, 4.91 ; \mathrm{S}, 6.51$.

$\left[\mathrm{Mo}(\mathrm{CO})_{5}(3)\right](\mathbf{9})$ : The above procedure leads to $149 \mathrm{mg}$ of $9(76 \%)$. IR $\left(\mathrm{CH}_{2} \mathrm{Cl}_{2}, \mathrm{~cm}^{-1}\right): 2018$, 1917, 1900, $1875\{v(\mathrm{CO})\} .{ }^{31} \mathrm{P}\left\{{ }^{1} \mathrm{H}\right\}-\mathrm{NMR}\left(\mathrm{CD}_{3} \mathrm{OD}, \delta\right.$ in ppm): 26.5 (s). ${ }^{1} \mathrm{H}-\mathrm{NMR}\left(\mathrm{CD}_{3} \mathrm{OD}, \delta\right.$ in ppm): 1.01 - 1.31 (m, $\left.\mathrm{PCH}_{2}\left(\mathrm{C}_{2}\right)_{6}\right), 1.31$ - $1.47\left(\mathrm{~m}, \mathrm{C}_{2} \mathrm{CH}_{2} \mathrm{CH}_{2} \mathrm{~S}\right), 1.70-1.82\left(\mathrm{~m}, \mathrm{C}_{2} \mathrm{CH}_{2} \mathrm{~S}\right)$, $1.97-2.08\left(\mathrm{~m}, \mathrm{PC} \underline{H}_{2}\right), 2.73-2.81\left(\mathrm{~m}, \underline{\mathrm{CH}}_{2} \mathrm{~S}\right), 7.27-7.49(\mathrm{~m}, \mathrm{Ph}) .{ }^{13} \mathrm{C}-\mathrm{NMR}\left(\mathrm{CD}_{3} \mathrm{OD}, \delta\right.$ in ppm): 23.7 (s, $\mathrm{PCH}_{2} \underline{C H}_{2}$ ), 24.5 (s, $\underline{\mathrm{C}} \mathrm{H}_{2} \mathrm{CH}_{2} \mathrm{~S}$ ), 28.3 (s, $\underline{\mathrm{C}} \mathrm{H}_{2} \mathrm{CH}_{2} \mathrm{CH}_{2} \mathrm{~S}$ ), 28.6-28.9 \{four singlets, $\mathrm{PCH}_{2} \mathrm{CH}_{2} \mathrm{CH}_{2}\left(\underline{C H}_{2}\right)_{4}$ \}, $30.3\left(\mathrm{AXX}\right.$ ', 3 lines, $\left.{ }^{2} \mathrm{~J}_{\mathrm{C}-\mathrm{P}}{ }^{4} \mathrm{~J}_{\mathrm{C}-\mathrm{P}},=12.5 \mathrm{~Hz}, \mathrm{PCH}_{2} \mathrm{CH}_{2} \underline{C H}_{2}\right), 32.2(\mathrm{AXX}$, 3 lines, $\left.{ }^{1} \mathrm{~J}_{\mathrm{C}-\mathrm{P}}+{ }^{3} \mathrm{~J}_{\mathrm{C}-\mathrm{P}},=21.6 \mathrm{~Hz}, \mathrm{PC} \underline{H}_{2}\right), 51.3\left(\mathrm{~s}, \underline{\mathrm{C}} \mathrm{H}_{2} \mathrm{~S}\right.$ ), 127.9-137.3 (multiple signals, Ph), 210.0 (t, ${ }^{2} \mathrm{~J}_{\mathrm{C}-\mathrm{P}}=9.7 \mathrm{~Hz}, \mathrm{CO}$ cis to the two P atoms), 215.3 (AXX', 3 lines, ${ }^{2} \mathrm{~J}_{\mathrm{C}-\mathrm{P}}+{ }^{2} \mathrm{~J}_{\mathrm{C}-\mathrm{P}}=16.0 \mathrm{~Hz}, \mathrm{CO}$ trans and cis to P atoms). MS-ESI (negative mode, $\mathrm{m} / \mathrm{z}$ ): 1043.1 ([M-Na]', $63 \%, 510.0$ ([M$\left.2 \mathrm{Na}]^{2-}, 100 \%\right)$. HRMS (ESI) calcd for $\mathrm{C}_{48} \mathrm{H}_{60} \mathrm{MoNaO}_{10} \mathrm{P}_{2} \mathrm{~S}_{2}$ ([M-Na] $]^{-}$1043.2032, found 1043.2032. Anal. Found: C, 53.73; H, 5.77; S, 5.69. Calcd for $\mathrm{C}_{48} \mathrm{H}_{60} \mathrm{MoNa}_{2} \mathrm{O}_{10} \mathrm{P}_{2} \mathrm{~S}_{2} \cdot 0.5 \mathrm{CH}_{4} \mathrm{O}$ : C, 53.89; H, 5.78; S, 5.93 . 


\section{High Resolution Mass Spectrometry}

a) Calculated and experimental isotopic distribution for $\left[\mathrm{Mo}(\mathrm{CO})_{5}(\mathbf{1})\right](\mathbf{4})$
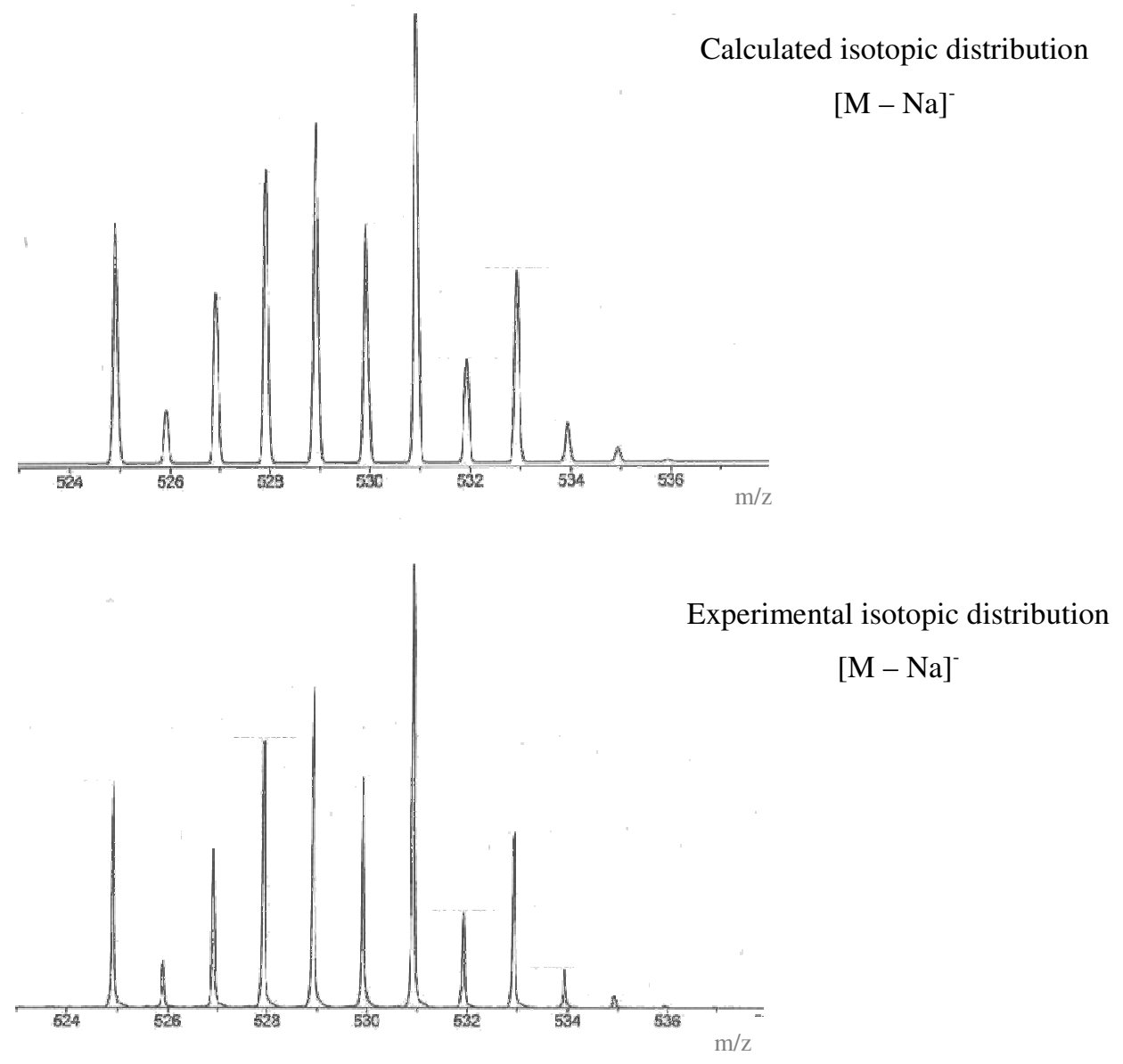

$[\mathrm{M}-\mathrm{Na}]^{-}: \mathrm{C}_{19} \mathrm{H}_{14} \mathrm{MoO}_{8} \mathrm{PS}$

Calculated: 524.9221, 525.9253, 526.9206, 527.9214, 528.9207, 529.9218, 530.9209, $531.9235,532.9224,533.9255,534.9231$.

Experimental: 524.9214, 525.9236, 526.9199, 527.9205, 528.9198, 529.9211, 530.9199, 531.9231, 532.9215, 533.9246, 534.9240. 
b) Calculated and experimental isotopic distribution for $\left[\mathrm{Mo}(\mathrm{CO})_{5}(\mathbf{2})\right](\mathbf{5})$
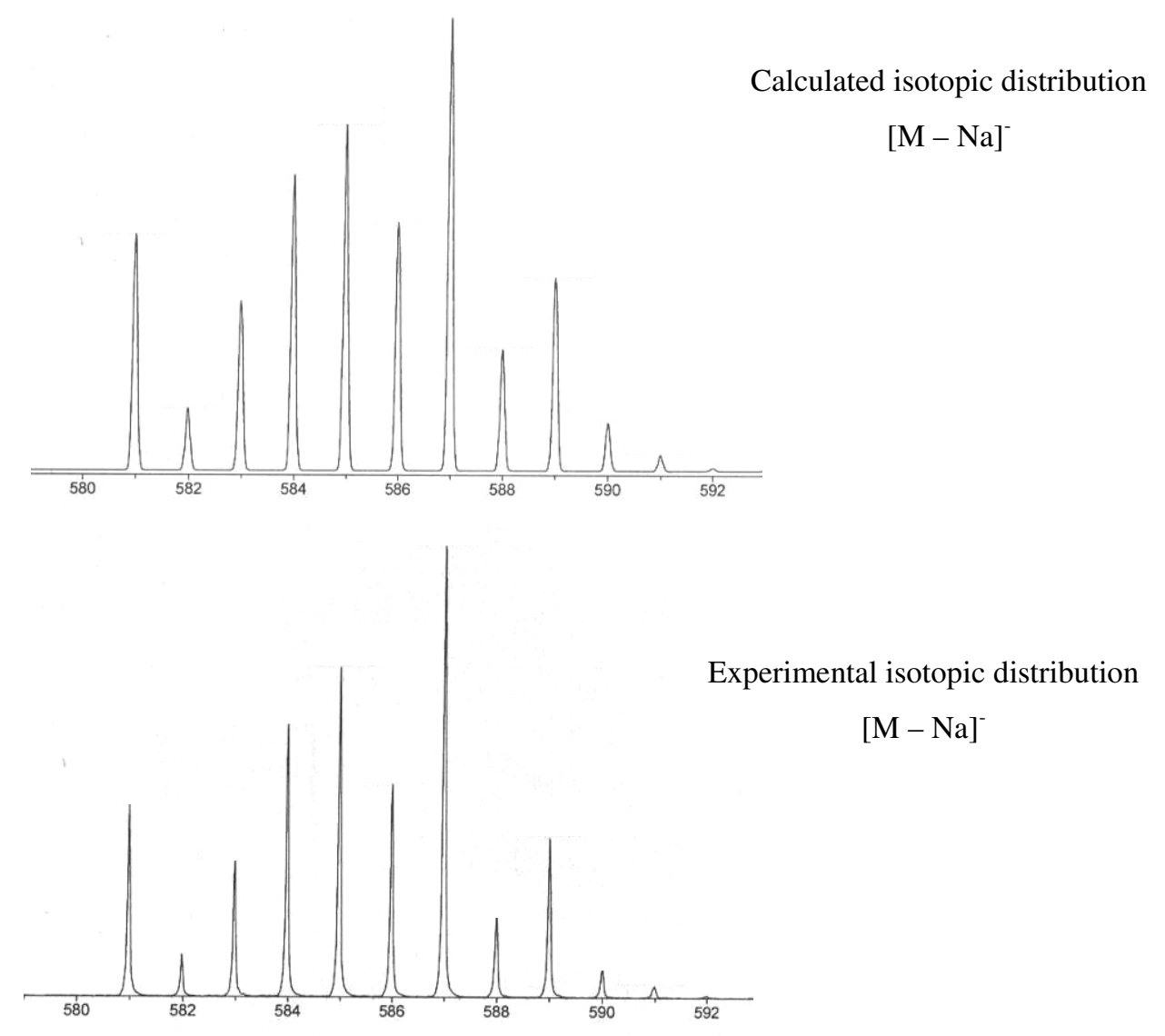

$[\mathrm{M}-\mathrm{Na}]^{-}: \mathrm{C}_{23} \mathrm{H}_{22} \mathrm{MoO}_{8} \mathrm{PS}$

Calculated: $\quad 580.9847,581.9879,582.9833,583.9841,584.9834,585.9845,586.9836$, $587.9863,588.9852,589.9882,590.9864$.

Experimental: $580.9830,581.9857,582.9805,583.9823,584.9816,585.9826,586.9820$, 587.9831, 588.9821, 589.9836, 590.9734. 
c) Calculated and experimental isotopic distribution for $\left[\mathrm{Mo}(\mathrm{CO})_{5}(\mathbf{3})\right](\mathbf{6})$
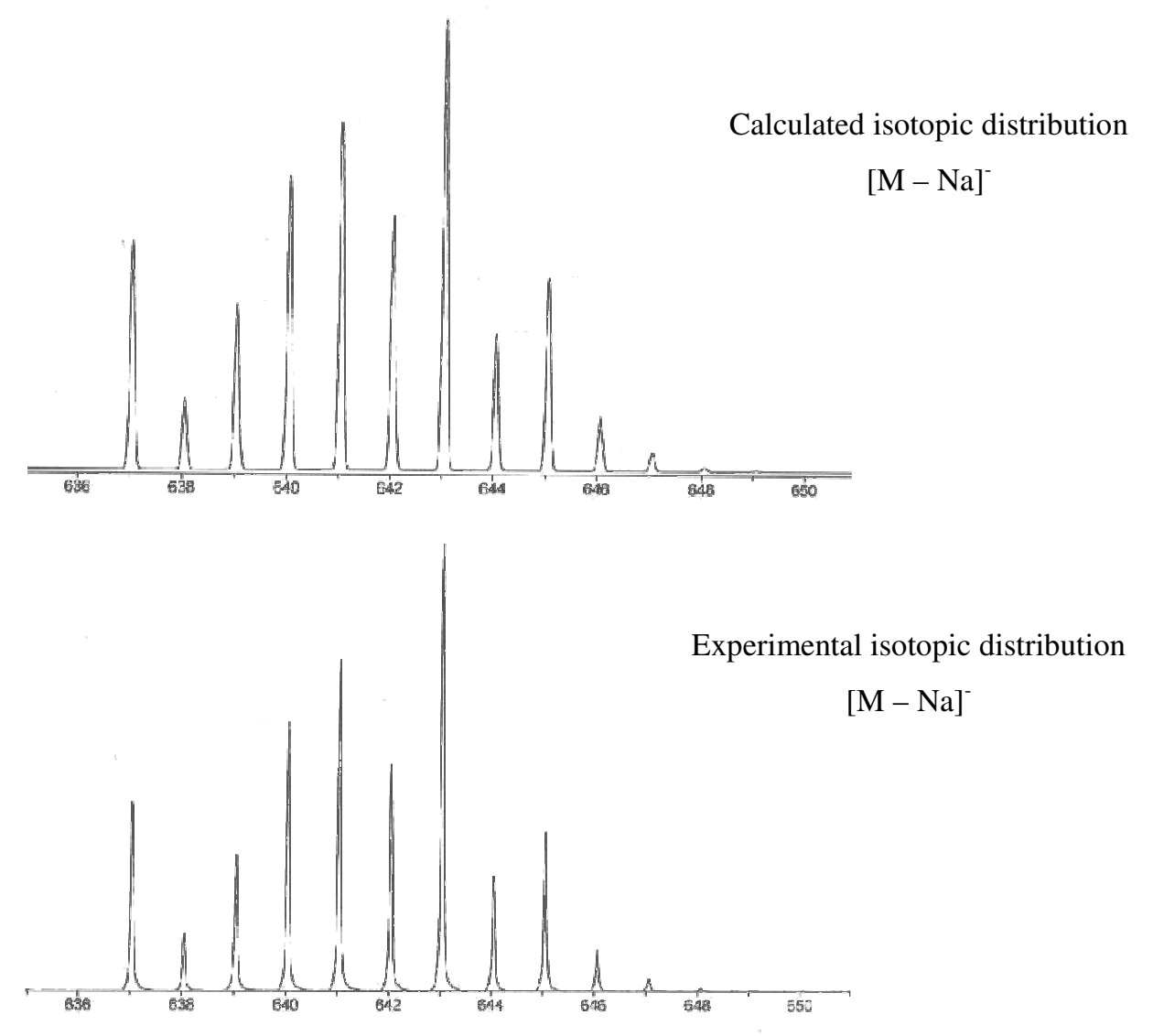

$[\mathrm{M}-\mathrm{Na}]^{-}: \mathrm{C}_{27} \mathrm{H}_{30} \mathrm{MoO}_{8} \mathrm{PS}$

Calculated: $\quad 637.0473,638.0506,639.0460,640.0467,641.0462,642.0473,643.0464$, 644.0490, 645.0479, 646.0509, 647.0497.

Experimental: $637.0460,638.0484,639.0445,640.0449,641.0445,642.0451,643.0447$, 644.0473, 645.0464, 646.0492, 647.0489. 
d) Calculated and experimental isotopic distribution for cis-[Mo(CO $\left.)_{4}(\mathbf{1})_{2}\right](\mathbf{7})$
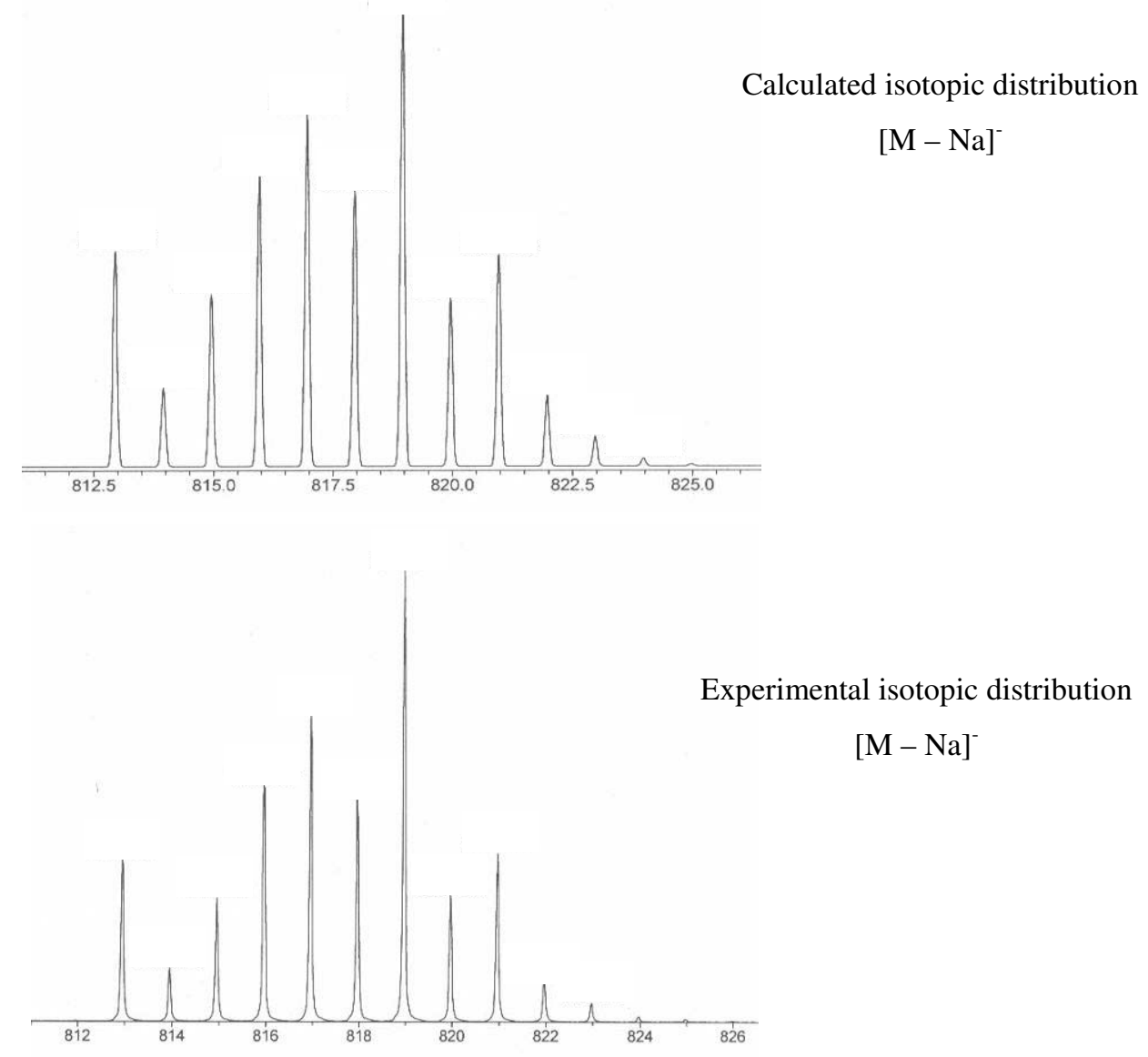

$[\mathrm{M}-\mathrm{Na}]^{-}: \mathrm{C}_{32} \mathrm{H}_{28} \mathrm{MoNaO}_{10} \mathrm{P}_{2} \mathrm{~S}_{2}$

Calculated: $\quad 812.9559,813.9592,814.9548,815.9555,816.9550,817.9559,818.9550$, $819.9573,820.9562,821.9590,822.9572$.

Experimental: 812.9556, 813.9593, 814.9543, 815.9554, 816.9549, 817.9561, 818.9550, 819.9576, 820.9559, 821.9591, 822.9580. 
e) Calculated and experimental isotopic distribution for $c i s-\left[\mathrm{Mo}(\mathrm{CO})_{4}(\mathbf{2})_{2}\right](\mathbf{8})$
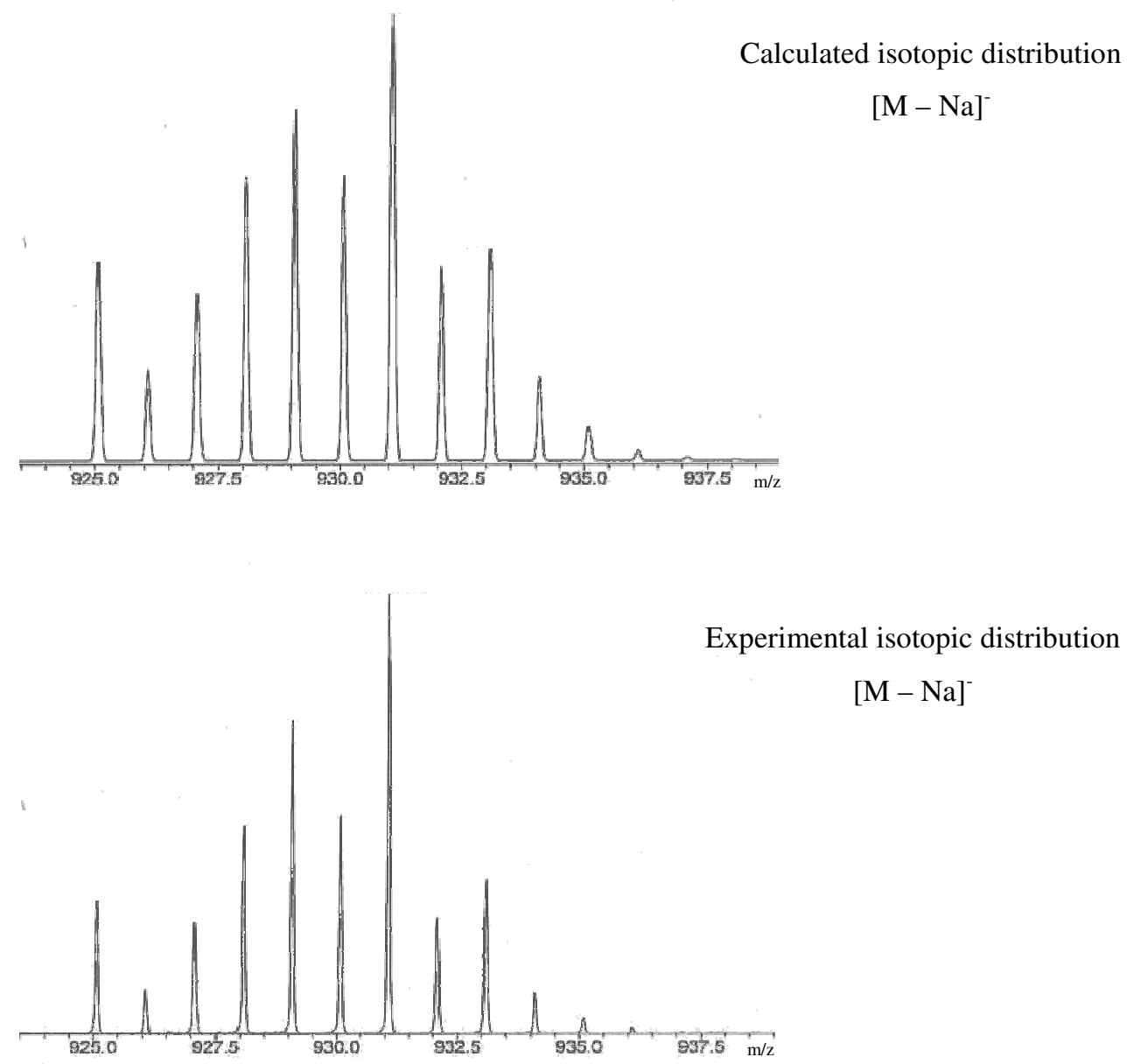

$[\mathrm{M}-\mathrm{Na}]^{-}: \mathrm{C}_{40} \mathrm{H}_{44} \mathrm{MoNaO}_{10} \mathrm{P}_{2} \mathrm{~S}_{2}$

Calculated: $\quad 925.0811,926.0844,927.0803,928.0808,929.0805,930.0814,931.0805$, 932.0828, 933.0818, 934.0843, 935.0834.

Experimental: 925.0785, 926.0813, 927.0779, 928.0788, 929.0781, 930.0792, 931.0795, 932.0816, 933.0803, 934.0824, 935.0815. 
f) Calculated and experimental isotopic distribution for $\operatorname{cis}-\left[\mathrm{Mo}(\mathrm{CO})_{4}(\mathbf{3})_{2}\right](\mathbf{9})$
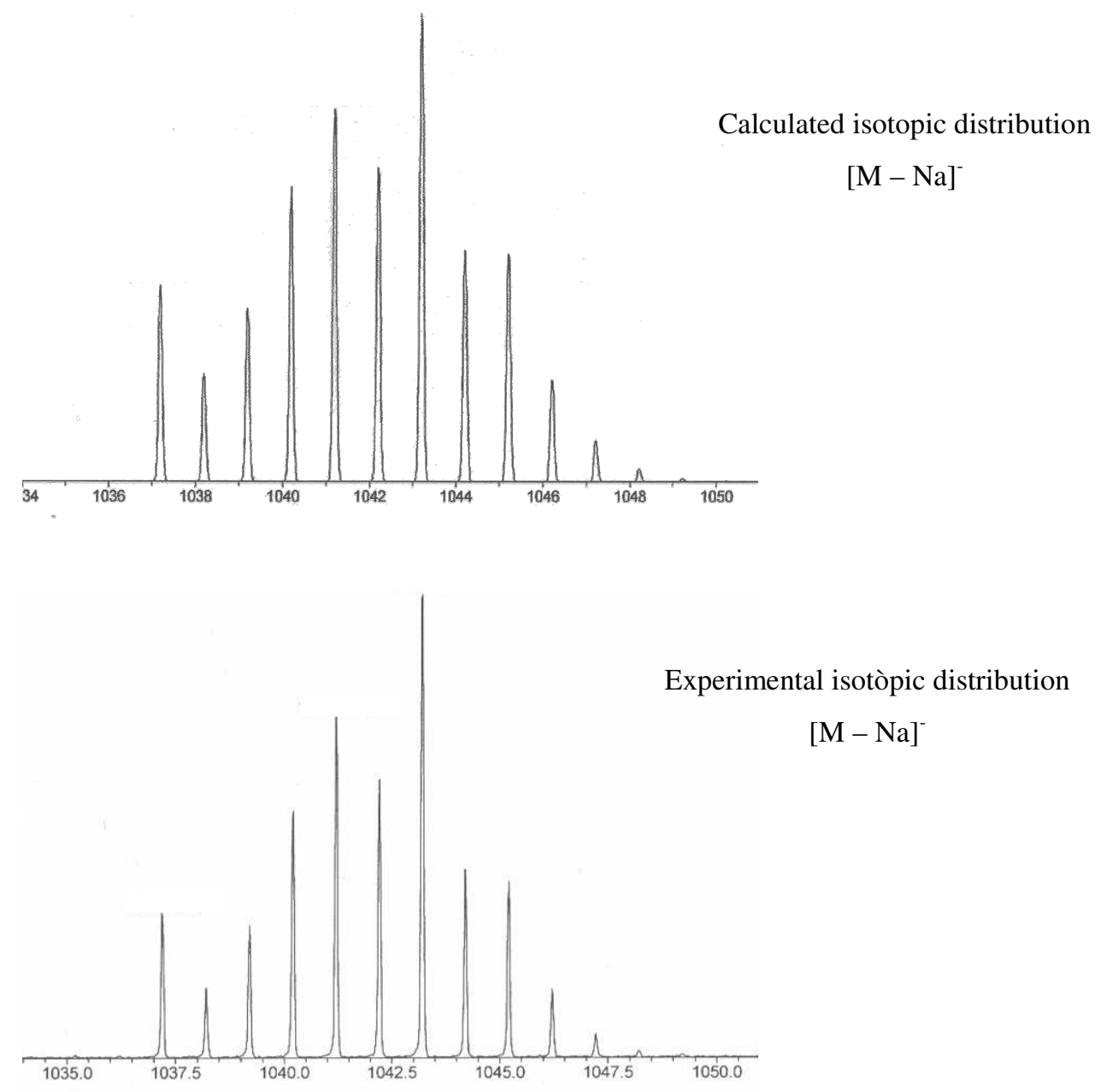

$[\mathrm{M}-\mathrm{Na}]^{-}: \mathrm{C}_{48} \mathrm{H}_{60} \mathrm{MoNaO}_{10} \mathrm{P}_{2} \mathrm{~S}_{2}$

Calculated: $\quad 1037.2063,1038.2096,1039.2059,1040.2062,1041.2059,1042.2068$, 1043.2059, 1044.2082, 1045.2073, 1046.2097, 1047.2095, 1048.2103.

Experimental: $1037.2021,1038.2072,1039.2021,1040.2029,1041.2029,1042.2029$, 1043.2032, 1044.2042, 1045.2028, 1046.2067, 1047.2075, 1048.2011. 
4. Surface Tension Measurements. The surface tension measurements of the aqueous solutions were performed in the Departament de Tecnologia de Tensioactius de l'Institut de Química Avançada de Catalunya (IQAC-CSIC) at $25{ }^{\circ} \mathrm{C}$ with a Krüss K-12 automatic tensiometer (Hamburg, Germany) equipped with a Wilhelmy plate. All compounds were previously recrystallized and lyophilized. The water solutions of amphiphiles were prepared with degassed Milli-Q water. The different solutions were prepared by dilution of a concentrated sample and then aged for at least $30 \mathrm{~min}$ before the determinations. The stability criterion for surface tension values was tuned to $\pm 0.1 \mathrm{mN} / \mathrm{m}$ for five consecutive measurements. The cmc values were taken from the intersection of two linear sections obtained in the graphical plots of surface tension versus logarithm of the concentration. The area occupied per molecule adsorbed at the water/air interface, expressed in $\AA^{2}$, was obtained from the equation $A=10^{16} / \mathrm{N}_{\mathrm{A}} \Gamma$, where $\mathrm{N}_{\mathrm{A}}$ is Avogadro's number and $\Gamma$ the surface excess concentration in $\mathrm{mol} / \mathrm{cm}^{2}$, calculated according to the Gibbs equation: $\Gamma=-(\mathrm{d} \gamma / \mathrm{d} \log C) / 2.303 n R T$, where $n$ is the number of molecular species in solution ( $\mathrm{n}=2$ for compounds 4-6 and $\mathrm{n}=3$ for compounds 7-9), and $(\mathrm{d} \gamma / \mathrm{d} \log C$ ) is the slope of the linear part of the graph obtained immediately below the cmc. 
a) Surface tension measurements for complexes (4-6)
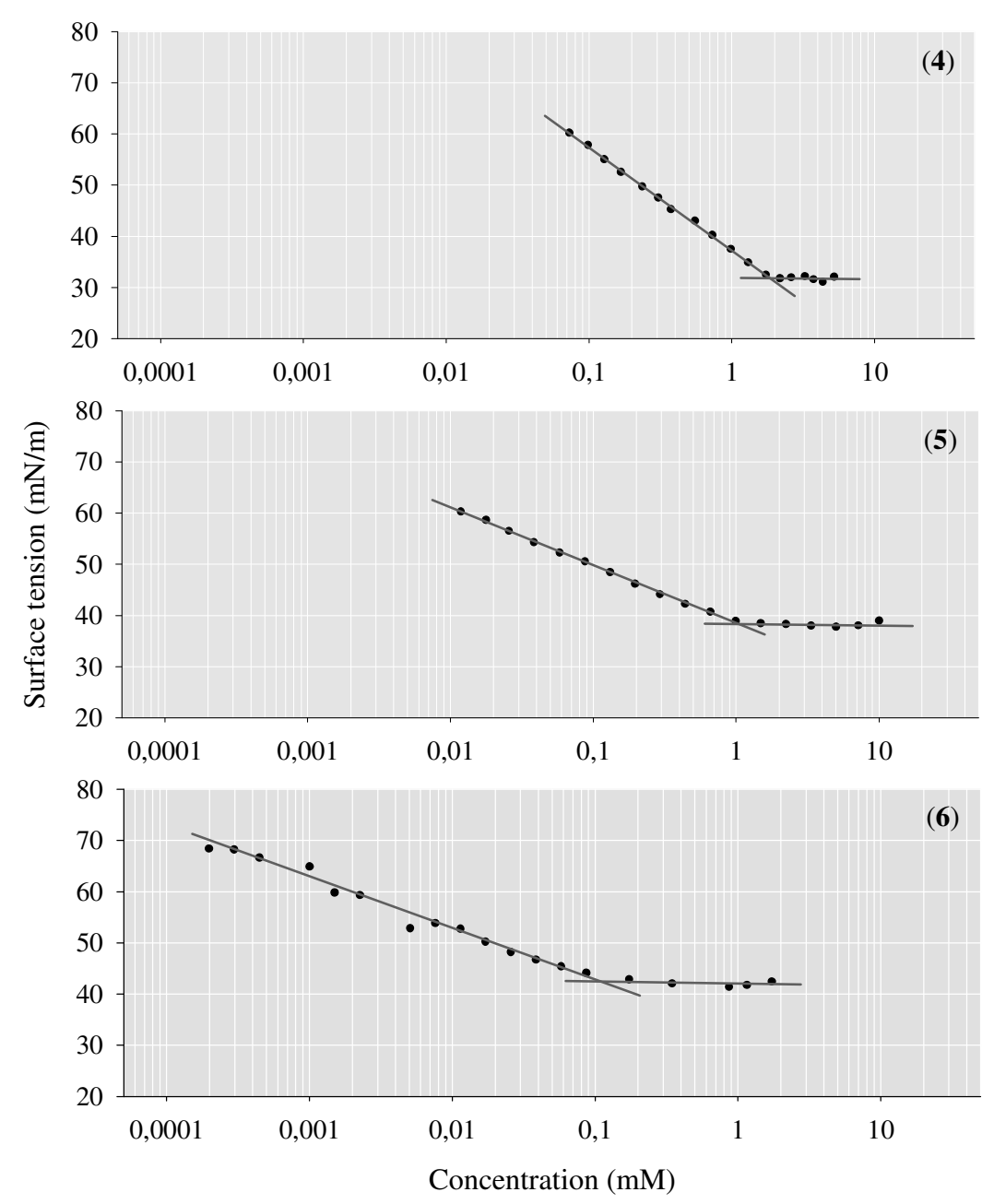
b) Surface tension measurements for complexes (7-9)
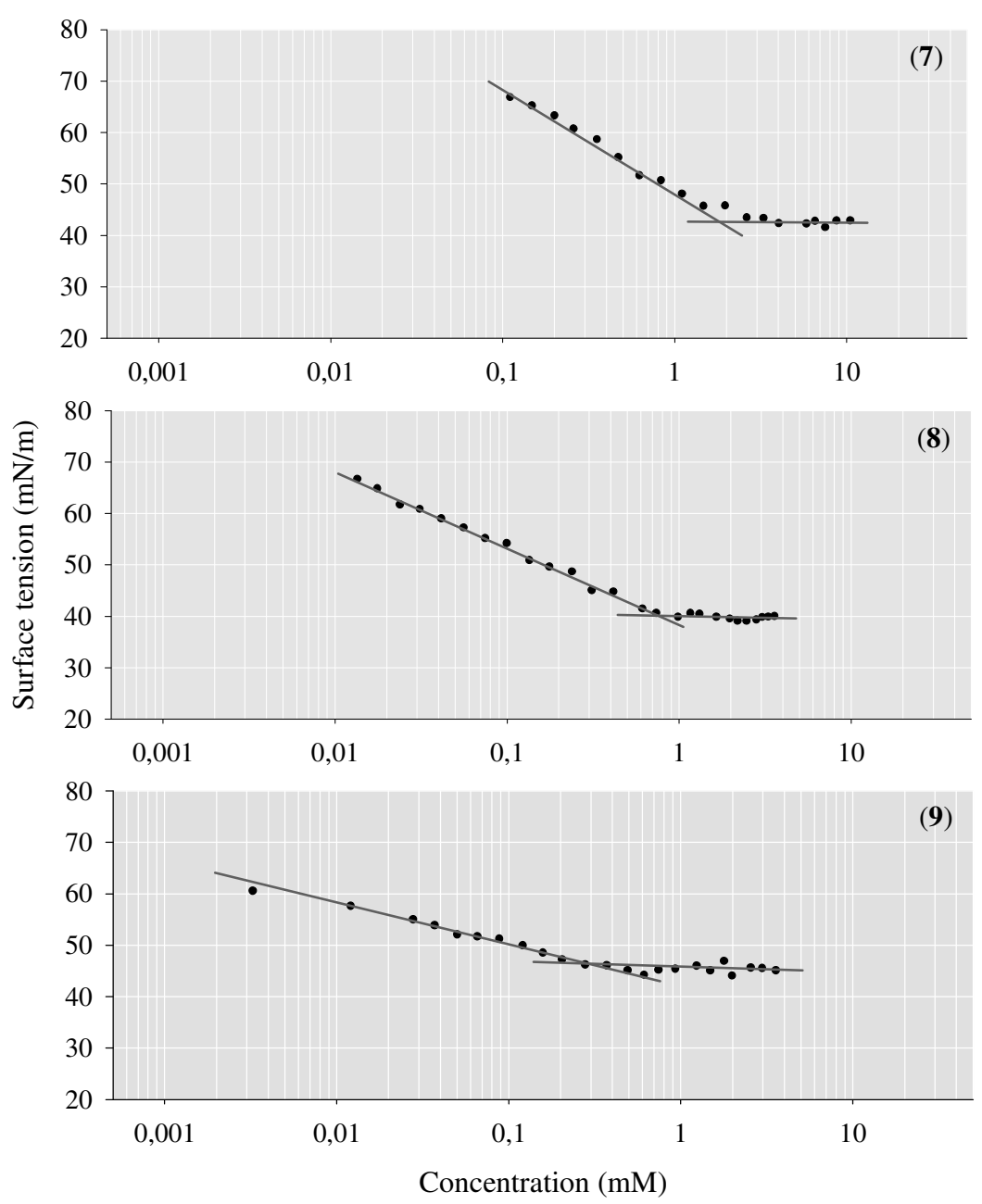


\section{TABLE OF CONTENTS ENTRY}

SUMMARY: Self-assembly of new metal carbonyl metallosurfactants prepared from surfactant phosphines leads to the formation of metallo-vesicles with an organometallic amphiphile bilayer.

GRAPHIC:

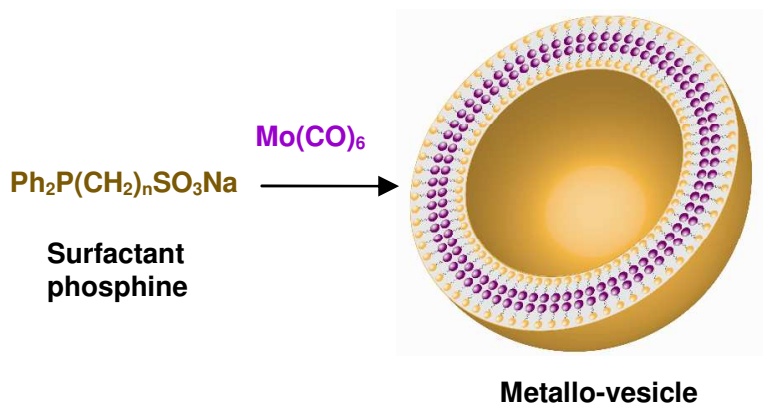

